\title{
Assessment of soil microbial and enzyme activity in the rhizosphere zone under different land use/cover of a semiarid region, India
}

\author{
Archana Meena ${ }^{1 *}$ (D) and K. S. Rao ${ }^{2}$
}

\begin{abstract}
Background: Land use/cover and management practices are widely known to influence soil organic matter $\left(\mathrm{S}_{\mathrm{OM}}\right)$ quality and quantity. The present study investigated the effect of different land use, i.e., forests viz. mixed forest cover (MFC), Prosopis juliflora (Sw.) DC-dominated forest cover (PFC), and cultivated sites viz. agriculture field $(\mathrm{AF})$, vegetable field $(\mathrm{VF})$, respectively, on soil parameter, microbial activity, and enzymes involved in soil nutrient cycle in a semiarid region of India.

Results: The results showed a significant reduction $(P<0.05)$ in soil carbon $\left(\mathrm{S}_{C}\right)$, soil nitrogen $\left(\mathrm{S}_{N}\right)$ content $(\sim 30-$ $80 \%)$ and consequently the soil microbial biomass carbon $\left(\mathrm{S}_{\mathrm{MBC}}\right)(\sim 70-80 \%)$, soil basal respiration $\left(\mathrm{S}_{B R}\right)$, soil substrate-induced respiration $\left(S_{\text {SIR }}\right)$, and soil enzyme activities ( $\beta$-glucosidase, acid phosphatase, and dehydrogenase) under cultivated sites in comparison with forest sites. Pearson's correlation showed that a positive correlation of $S_{C}$ with $S_{M B C}, S_{B R}, S_{S I R}(P<0.01)$, and enzymatic activities (i.e., $\beta$-glucosidase, dehydrogenase) $(P<0.05)$ may imply the critical role of $S_{C}$ in regulating microbial and enzymatic activity. Also, a positive correlation of soil moisture with urease activity $(P<0.01)$ was found suggesting it as a significant abiotic factor for soil biological functions. Additionally, based on the PCA analysis, we observed the clustering of $\mathrm{S}_{\mathrm{MBC}} / \mathrm{S}_{\mathrm{C}}$ ratio and $\mathrm{qCO}_{2}$ nearby AF.

Conclusion: Our study suggests that soil microbial parameters $\left(S_{M B C}, S_{B R}, S_{S I R}, S_{M B C} / S_{C}, q_{C O}\right)$ and enzyme activity are key indicators of soil health and fertility. Land use/cover alters the $S_{O M}$ content and soil microbial functions. The management strategies focusing on the conservation of natural forest and minimizing the land disturbances will be effective in preventing soil carbon flux as $\mathrm{CO}_{2}$ and maintaining the $\mathrm{S}_{\mathrm{C}}$ stock.
\end{abstract}

Keywords: Land use changes, Soil microbes, Soil enzymes, Semiarid ecosystems, Land management practices

\section{Background}

Land-use/cover change is considered as one of the major factors of global climate change, biodiversity loss, and ecological degradation (Kooch et al. 2018). In the semiarid tropics of India, the rapid population growth requires continuous expansion of cultivated lands to support food demand, economic development, and

\footnotetext{
* Correspondence: archanam417@gmail.com

'Department of Botany, University of Rajasthan, Jaipur, Rajasthan 302004, India

Full list of author information is available at the end of the article
}

reduce poverty (Wani et al. 2015). Deforestation and land use conversions are major ecological problems in these regions. The conversion of natural forest into agricultural land significantly alter the soil processes and properties, and therefore, soil functioning (Celik 2005; Dawson and Smith 2007). Previous studies have reported that land use/cover would affect the soil physical, chemical, biological properties, and also soil organic matter $\left(\mathrm{S}_{\mathrm{OM}}\right)$ dynamics, which subsequently alters the soil quality and fertility (Zhao et al. 2013). Further, the variation in land use/cover influences the soil microbial functions 
by affecting the soil carbon $\left(\mathrm{S}_{\mathrm{C}}\right)$ and nitrogen $\left(\mathrm{S}_{\mathrm{N}}\right)$ cycle (Sousa et al. 2012). Microbial indices related to $S_{\mathrm{OM}}$ such as soil microbial biomass carbon $\left(\mathrm{S}_{\mathrm{MBC}}\right)$ and nitrogen $\left(\mathrm{S}_{\mathrm{MBN}}\right)$, basal respiration $\left(\mathrm{S}_{\mathrm{BR}}\right)$, substrate-induced respiration $\left(\mathrm{S}_{\mathrm{SIR}}\right)$ (Anderson and Domsch 1978), and microbial (MQ) and metabolic quotients $\left(\mathrm{qCO}_{2}\right)$ are a good indicator of soil nutrient dynamics (Raiesi and Beheshti 2014; Goenster et al. 2017) and would provide an early warning of soil quality deterioration (Cookson et al. 2007; Huang and Song 2010).

Soil microbes despite comprising a small fraction of the total mass of $\mathrm{S}_{\mathrm{OM}}$ play a critical role in soil processes, $\mathrm{S}_{\mathrm{OM}}$ decomposition, nutrient cycling, etc. They are significantly influenced by human interventions involving land conversions (Smith and Paul 1995; Kabiri et al. 2016). Additionally, the management practices, variation in quality and availability of substrate, fine roots activity, litter quality, vegetation composition, plant biomass, and belowground processes also change the $\mathrm{S}_{\mathrm{OM}}$ content, hence, affect the soil microbial community structure and functions. Recently, there has been an increased interest in the studies investigating the effect of conversion of natural forests into farmlands and agricultural management practices on soil microbial community structure and functions (Ye et al. 2009; Nielsen and Ball 2015; Goenster et al. 2017; Thapa et al. 2018; Lacerda-Júnior et al. 2019).

Soil enzyme activities are the indicators of microbial community and functions. They reflect changes in soil biochemical processes and $\mathrm{S}_{\mathrm{OM}}$ dynamics attributed to human-induced variation in abiotic and biotic factors in soil (Trasar-Cepeda et al. 2008). Soil enzyme activities related to $\mathrm{S}_{\mathrm{MBC}}$ and soil organic carbon (SOC) are often used for comparison of different land use with varying $\mathrm{S}_{\mathrm{OM}}$ content (Waldrop et al. 2004; Bastida et al. 2007). Measurement of soil enzyme activities in key nutrient cycling $(\mathrm{C}, \mathrm{N}$, and $\mathrm{P})$ and oxidation-reduction processes have been used widely as a potential indicator for determining the effect of land use conversions and management practices on soil health (Acosta-Martínez et al. 2007; Pandey et al. 2014; de Medeiros et al. 2015). Therefore, an investigation of soil microbial characters and enzyme activities is critical in studying the land conversions and focusing the soil management.

Principal component analysis (PCA) has been widely used as a statistical tool to determine the most sensitive factor explaining the significant variation among the different land use/cover (Notaro et al. 2014; Pandey et al. 2014; de Medeiros et al. 2015, 2017; Moghimian et al. 2017).

Previous studies in India evaluated the effect of land use conversions on soil microbiota and soil enzymes (Singh and Ghoshal 2014; Kumar and Ghosal 2017; Rai et al. 2018; Tiwari et al. 2019). However, not many such studies have compared the soil microbial parameters and enzymes in different land use/cover in semiarid regions of India. The present study was conducted in forests and agroecosystems of Delhi, India. Delhi, being an urban city, is among the most polluted cities in the world. It is one of the largest growing cities with a decadal growth of $21.20 \%$ and a population of 16.8 million (Census of India 2011). Rapid population growth and growing economy are the main drivers of land use/land cover changes (Jain et al. 2016). The forest ecosystems are notified as reserved and are located on ridge areas which are the extensions of Aravalli hills with a length of $32 \mathrm{~km}$. The growing urbanization and encroachment have led to the complete loss of vegetation, and only a few areas of the forests have been protected in Delhi (Sinha 2014). The impact of urbanization processes, such as land use conversions, deforestation, and the shift in vegetation composition, is known to alter soil structure and physicochemical properties (Pickett et al. 2001; Yan et al. 2016). It is assumed that these processes will influence soil nutrient cycling and affect soil microbial functions and enzyme activities (Rai et al. 2018). This study hypothesizes that soil microbiological and enzyme attributes vary across different land use/cover, and therefore, could be used as sensitive indicators of soil health. The purpose of this study is to evaluate the effect of different land use/cover types (i.e., forest cover and cultivated land) on soil microbial parameters $\left(\mathrm{S}_{\mathrm{MBC}}, \mathrm{S}_{\mathrm{BR}}, \mathrm{S}_{\mathrm{SIR}}\right.$, $\mathrm{S}_{\mathrm{MBC}} / \mathrm{S}_{\mathrm{C}}, \mathrm{qCO}_{2}$ ). Further, the study also determines the activity of selected soil enzymes involved in soil nutrient cycling, i.e., carbon ( $\beta$-glucosidases), nitrogen (ureases), phosphorus (acid phosphatase), and oxidation-reduction (dehydrogenase) under selected land use/cover types. Lastly, the purpose is also to understand the influence of land use/cover on the relationship among soil physicochemical properties and microbial and enzyme activity.

\section{Materials and methods Study area}

This study was carried out in a semiarid region of Delhi, which is part of the National Capital Territory (NCT) of India, lies between $28.41^{\circ} \mathrm{N}$ and $28.41^{\circ} \mathrm{N} ; 76.84^{\circ} \mathrm{E}$ and $77.40^{\circ} \mathrm{E}$, and covers an area of $1483 \mathrm{~km}^{2}$. It is bounded by the Indo-Gangetic alluvial plains, Thar Desert, and Aravalli Range. The climate of Delhi is semiarid and dry and greatly influenced by the Himalayas and the Thar Desert due to its proximity. The climate is characterized by hot summers (April-June), monsoons (July-September), and cool and dry winters (November-December). The study area receives most of the annual rainfall during the monsoon season. The vegetation of the study area is ravine thorn forest, which belongs to the ecosystem type of tropical thorn forest $(6 \mathrm{~B} / \mathrm{C})$ (Champion and Seth 1968) and covers 33\% of the total forest area, 
whereas $67 \%$ is covered by plantation/tree outside forest (TOF) areas (FSI 2017). The vegetation is mainly dominated by middle-story thorny trees, which ate interspersed with open patches due to their scattered distribution (Sinha 2014). The parent material of Delhi ridge soil is quartzite or sandstone, with sandy loam to loam texture (Chibbar 1985). Prosopis juliflora, which is an exotic species, is the dominant tree in the forest. Acacia nilotica (L.) Delile, Acacia leucophloea (Roxb.) Willd., Salvadora oleoides Decne, and Cassia fistula L. are among the commonly found native trees (Sinha 2014; Meena et al. 2016). For the study, four sites were selected with two sites each for agriculture and forest land use, respectively, in the semiarid region of Delhi. The sites were selected on the basis of predominant land use activity, level of anthropogenic intervention and vegetation cover as (i) mixed forest cover (MFC), (ii) $P$. juliflora-dominated forest cover (PFC), (iii) agriculture field (AF), and (iv) vegetable field (VF) (Meena et al. 2020). The mixed forest cover (MFC) was considered as a native vegetation cover $(28.68 \mathrm{~N} ; 77.22 \mathrm{E})$. In MFC, $P$. juliflora was found to be the most dominant species but other associated tree species viz. Pongamia pinnata L., Azadirachta indica Juss., A. nilotica, and C. fistula were also observed (Meena et al. 2019). The P. juliflora-dominated forest cover (PFC) is an exotic tree cover $\left(28.69^{\circ}\right.$ $\mathrm{N} ; 77.22^{\circ} \mathrm{E}$ ). The agriculture field (AF) was located near the Nazafgarh drain $\left(28.54^{\circ} \mathrm{N} ; 77.87^{\circ} \mathrm{E}\right)$ and was mainly cropped with wheat (Triticum aestivum L.) from October to May and common bean (Phaseolus vulgaris L.) from September to October. The AF was irrigated by a tube well during the growing season. Lastly, the vegetable field (VF) was located along the Yamuna flood plains $\left(28.53^{\circ} \mathrm{N} ; 77.33^{\circ} \mathrm{E}\right)$. The major vegetable grown were chilies (Capsicum annum L.) throughout the year except between September and November, during which cabbage (Brassica oleraceae L.) was grown. The water pumped regularly from the Yamuna River for irrigation in the VF. The management practices such as tillage, pesticide and fertilizer application, runoffs, and plant or crop rotation in cultivated lands are expected to affect the soil microbes. The soil physicochemical properties of the sites are given in Table 1.

\section{Soil sampling and analysis}

The sampling was conducted by randomized quadrat sampling experimental design during September 2012. For each land use, three quadrats of $10 \times 10 \mathrm{~m}$ were selected for soil collection. The sampling points were ensured to be homogenous with respect to elevation and slope. From each quadrat, the soil samples were collected after removing the litter from five different points at $0-10-\mathrm{cm}$ depth and pooled together to obtain a composite sample. Therefore, three soil samples were
Table 1 Soil physical and chemical factors of four land uses of the semiarid region of Delhi

\begin{tabular}{lllll}
\hline Soil parameters & PFC & MFC & AF & VF \\
\hline $\mathbf{S}_{\mathbf{C}} / \mathbf{S}_{\mathbf{N}}$ & $9.52(0.11)^{\mathrm{a}}$ & $10.15(0.08)^{\mathrm{a}}$ & $9.5(0.18)^{\mathrm{b}}$ & $12.4(0.09)^{\mathrm{c}}$ \\
$\mathrm{S}_{\boldsymbol{P}}\left(\mathrm{mg} \mathrm{L}^{-1}\right)$ & $2.22(0.01)^{\mathrm{a}}$ & $1.95(0.02)^{\mathrm{b}}$ & $1.73(0.02)^{\mathrm{c}}$ & $1.84(0.62)^{\mathrm{bc}}$ \\
$\mathbf{S}_{\mathbf{M}}(\%)$ & $3.57(0.03)^{\mathrm{a}}$ & $5.41(0.05)^{\mathrm{b}}$ & $3.92(0.05)^{\mathrm{c}}$ & $4.70(0.02)^{\mathrm{d}}$ \\
Soil texture & Sandy loam & Sandy loam & Loamy sand & Sandy loam
\end{tabular}

Values are means (standard error) and letters denote significant difference among land use types $(P<0.05)$

$S_{C} / S_{N}$ soil carbon to soil nitrogen ratio, $S_{P}$ soil phosphorus, $S_{M}$ soil moisture, PFC $P$. juliflora forest cover, MFC mixed forest cover, $A F$ agriculture field, $V F$ vegetable field

selected for each land use type, with a total of 12 samples. The visible root mass was removed from the soil samples by hand. The litter layer was removed thoroughly before analysis. The soil samples were passed through a 2-mm sieve, ground in a mortar with a pestle, and stored at room temperature for further analysis. The soil moisture $\left(\mathrm{S}_{\mathrm{M}}\right)$ content was measured using the gravimetric method. For microbial parameters and enzymes, a subsample of 2-mm freshly sieved soil was stored in zipped plastic bags at $4{ }^{\circ} \mathrm{C}$ till further analysis. $\mathrm{S}_{\mathrm{C}}$ and $\mathrm{S}_{\mathrm{N}}$ concentrations were measured using the CHNS Analyzer (Elementar vario). Available $\mathrm{S}_{\mathrm{P}}$ was measured by using an ammonium molybdate blue method (Allen et al. 1974).

\section{Soil microbial biomass carbon $\left(\mathrm{S}_{\mathrm{MBC}}\right)$, basal $\left(\mathrm{S}_{\mathrm{BR}}\right)$ and substrate-induced respiration $\left(\mathrm{S}_{\mathrm{SIR}}\right)$}

The $\mathrm{S}_{\mathrm{MBC}}$ was estimated by using the chloroform fumigation extraction method (Witt et al. 2000), where $35 \mathrm{~g}$ of fresh soil was fumigated with $2 \mathrm{ml}$ ethanol-free $\mathrm{CHCl}_{3}$ and incubated for $24 \mathrm{~h}$ in the dark at $25{ }^{\circ} \mathrm{C}$. The fumigated soils were extracted with $140 \mathrm{ml}$ of $0.5 \mathrm{M} \mathrm{K}_{2} \mathrm{SO}_{4}$, and unfumigated control soils were extracted immediately without fumigation. The resulting extracts were filtered and examined by the TOC analyzer (Elementar vario). The $\mathrm{S}_{\mathrm{MBC}}$ was calculated as the difference between fumigated and unfumigated sample with a conversion factor of 0.38 (Vance et al. 1987).

The $\mathrm{S}_{\mathrm{BR}}$ was measured by the alkali absorption method (Isermayer 1952). Briefly, $50 \mathrm{~g}$ of soil preincubated at $60 \%$ water-holding capacity (WHC) was incubated with $10 \mathrm{ml} 0.05 \mathrm{M} \mathrm{NaOH}$ solution at $25^{\circ} \mathrm{C}$ for 24 h. After incubation, $2 \mathrm{ml} \mathrm{BaCl} 2(0.5 \mathrm{M})$ and 2-3 drops of phenolphthalein indicator were added into the $\mathrm{NaOH}$ beaker which was then titrated with $0.1 \mathrm{M} \mathrm{HCl}$ dropwise. The $\mathrm{S}_{\mathrm{SIR}}$ of soil was estimated by the rate of initial maximal respiration of microorganisms after the amendment of soil subsamples with glucose (Anderson and Domsch 1978). The preincubated soil subsamples $(60 \%$ WHC) was mixed with glucose (30 $\mathrm{mg} \mathrm{g}^{-1}$ soil) and incubated with $0.05 \mathrm{M} \mathrm{NaOH}$ at $22{ }^{\circ} \mathrm{C}$ for $3 \mathrm{~h}$. The $\mathrm{CO}_{2}$ 
released was measured by titrating the $\mathrm{NaOH}$ solution with $0.1 \mathrm{M} \mathrm{HCl}$. The $\mathrm{S}_{\mathrm{BR}}$ and $\mathrm{S}_{\mathrm{SIR}}$ were expressed as $\mathrm{CO}_{2} \mathrm{C} \mathrm{mg} \mathrm{g}^{-1} \mathrm{~h}^{-1}$.

\section{Soil enzyme activities}

The $\beta$-glucosidase activity was estimated by using $\mathrm{p}$ nitrophenyl- $\beta$ - $D$-glucoside (PNG) as a substrate and incubating $1 \mathrm{~g}$ of soil with $0.25 \mathrm{ml}$ toluene, $4 \mathrm{ml}$ modified universal buffer (pH 6), and $1 \mathrm{ml}$ PNG solution (25 $\mathrm{mM}$ ) for $1 \mathrm{~h}$ at $37^{\circ} \mathrm{C}$ (Eivazi and Tabatabai 1988). After incubation, $1 \mathrm{ml}$ of $\mathrm{CaCl}_{2}$ solution and $4 \mathrm{ml}$ Tris buffer ( $\mathrm{pH}$ 12) were added, and absorbance was taken at 400 nm using a spectrophotometer (RIGOL, USA). The activity of $\beta$-glucosidase was expressed as $\mu \mathrm{g}$ PNG g ${ }^{-1} \mathrm{dwt}$ $\mathrm{h}^{-1}$ at $37^{\circ} \mathrm{C}$. The urease activity was determined by using urea as a substrate as described by Yao et al. (2006). Five grams of moist soil was incubated with $1 \mathrm{ml}$ methylbenzene, $10 \mathrm{ml}$ of $10 \%$ urea $20 \mathrm{ml}$ citrate buffer (pH 6.7) for $24 \mathrm{~h}$ at $37^{\circ} \mathrm{C}$. One milliliter of filtered soil solution, $1 \mathrm{ml}$ of sodium phenolate, and $3 \mathrm{ml}$ of sodium hypochlorite were added and diluted to $50 \mathrm{ml}$, and absorbance was determined at $578 \mathrm{~nm}$ using a spectrophotometer (RIGOL, USA). The activity of urease was expressed as $\mathrm{NH}_{3}-\mathrm{N} \mathrm{g}^{-1} \mathrm{~h}^{-1}$ at $37{ }^{\circ} \mathrm{C}$. Acid phosphatase activity was analyzed using p-nitrophenyl phosphate (p-NPP) as substrate as described by Schneider et al. (2000). Five grams of moist soil was mixed with $20 \mathrm{ml}$ acetate buffer $(\mathrm{pH}$ 5.2) and $100 \mathrm{mM}$ p-NPP and incubated at $30{ }^{\circ} \mathrm{C}$ for 30 min. After incubation, $1 \mathrm{ml}$ of $\mathrm{CaCl}_{2}$ and $4 \mathrm{ml}$ of $0.2 \mathrm{M}$ $\mathrm{NaOH}$ were added after incubation in order to terminate the reaction. The absorbance was determined using the spectrophotometer at $405 \mathrm{~nm}$ (RIGOL, USA). The activity of AP was expressed as $\mu \mathrm{g}$ p-NPP $\mathrm{g}^{-1} \mathrm{~h}^{-1}$ at $30{ }^{\circ} \mathrm{C}$. Dehydrogenase activity was measured using triphenyl tetrazolium chloride (TTC) as a substrate (Thalmann 1968), where the TTC solution $(0.3-0.4 \mathrm{~g} / 100 \mathrm{ml})$ was mixed with $5 \mathrm{~g}$ of moist soil and incubated for $24 \mathrm{~h}$ at $30{ }^{\circ} \mathrm{C}$. After incubation, $40 \mathrm{ml}$ of acetone was added, and absorbance was determined at $546 \mathrm{~nm}$ using a spectrophotometer (RIGOL, USA). The activity of dehydrogenase was expressed as $\mu$ g TTC $g^{-1} h^{-1}$.

\section{Statistical analysis}

One-way analysis of variance (ANOVA) was used to evaluate the effect of land use on selected variables $\left(\mathrm{S}_{\mathrm{M}}, \mathrm{S}_{\mathrm{P}}, \mathrm{S}_{\mathrm{C}}, \mathrm{S}_{\mathrm{N}}, \mathrm{S}_{\mathrm{MBC}}, \mathrm{S}_{\mathrm{BR}}, \mathrm{S}_{\mathrm{SIR}}, \mathrm{S}_{\mathrm{MBC}} / \mathrm{S}_{\mathrm{C}}, \mathrm{qCO}_{2}, \beta-\right.$ glucosidases, ureases, acid phosphatase, dehydrogenase activity) using Tukey's test at $P<0.05$. Pearson correlation analysis was performed to estimate the correlation of selected variables among the land use. All the statistical analysis was done using SPSS version 16.0. Principal component analysis (PCA) was used to evaluate the relationship of multivariate data using XLSTAT 2020.

\section{Results}

\section{Soil chemical and microbial parameters}

The $S_{C}$ and $S_{N}$ concentrations $\left(\mathrm{g} \mathrm{kg}^{-1}\right)$ at $0-10-\mathrm{cm}$ depth were found to be significantly influenced by land use type (Fig. 1a, b). Both $S_{C}$ and $S_{N}$ were higher under natural forests as compared with arable soils. The highest $\mathrm{S}_{\mathrm{C}}$ and $\mathrm{S}_{\mathrm{N}}\left(\mathrm{g} \mathrm{kg}^{-1}\right)$ were evaluated under MFC (47.70 \pm $1.16 ; 4.70 \pm 0.12)$ followed by PFC (31.70 $\pm 0.06 ; 3.33 \pm$ $0.033), \operatorname{VF}(12.40 \pm 0.01 ; 1 \pm 0)$, and $\operatorname{AF}(5.70 \pm 0.20$; $0.60 \pm 0.03)$, respectively. The $S_{C}$ and $S_{N}$ were significantly different among the four land uses $(P<0.05)$.

Similar to the $\mathrm{S}_{\mathrm{C}}$, higher $\mathrm{S}_{\mathrm{MBC}}$ was estimated under forest as compared with cultivated land uses (Fig. 1c) and followed the trend as MFC > PFC > VF > AF $(313.54 \pm 0.34,209.98 \pm 0.63,86.57 \pm 0.53$, and $62.57 \pm$ 0.29 , respectively). The $S_{M B C}$ was significantly different among the four land uses $(P<0.05)$. The $\mathrm{S}_{\mathrm{MBC}} / \mathrm{S}_{\mathrm{C}}$ was highest under AF (1.1), followed by VF (0.7), PFC (0.66), and MFC (0.65), respectively (Fig. 2a).

The $S_{\mathrm{BR}}$ was greater under forest as compared to cultivated sites and followed the trend as MFC $>$ PFC $>$ VF $>$ $\mathrm{AF}(22.20 \pm 0.07,18.77 \pm 0.09,10.63 \pm 0.12$, and $9.03 \pm$ $0.14 \mu \mathrm{g} \mathrm{g}^{-1} \mathrm{~h}^{-1}$, respectively) (Fig. 1d). The $\mathrm{S}_{\mathrm{SIR}}$ also followed similar trend as $143.50 \pm 0.15,119.51 \pm 0.16$, $95.06 \pm 0.11$, and $81.48 \pm 0.11 \mu \mathrm{g} \mathrm{g}^{-1} \mathrm{~h}^{-1}$ for MFC, PFC, $\mathrm{VF}$, and AF, respectively (Fig. 1e). Both $\mathrm{S}_{\mathrm{BR}}$ and $\mathrm{S}_{\mathrm{SIR}}$ varied significantly among the land use (MFC, PFC, VF, AF; $P<0.05)$. The metabolic quotient $\left(\mathrm{qCO}_{2}\right)$ was used to evaluate the efficiency of $\mathrm{S}_{\mathrm{MBC}}$ in utilizing the $\mathrm{S}_{\mathrm{C}}$ (Anderson and Domsch 1990). The value of $\mathrm{qCO}_{2}$ was estimated to be 0.14, 0.12, 0.09, and $0.07 \mu \mathrm{g} \mathrm{S}_{\mathrm{MBC}} \mathrm{g}^{-1} \mathrm{~h}^{-1}$ for $\mathrm{AF}, \mathrm{VF}, \mathrm{PFC}$, and MFC, respectively. A significant increase in $\mathrm{qCO}_{2}$ was observed under cultivated as compared with forest land use (Fig. 2b).

\section{Soil enzyme activity}

The activity of selected enzymes is shown in Fig. 3a, b, c, and $\mathrm{d}$. The $\beta$-glucosidase activity $\left(\mu \mathrm{g}\right.$ PNG g $\mathrm{g}^{-1} \mathrm{~h}^{-1}$ ) was significantly high in MFC $(623.71 \pm 5.75)$ than PFC $(398.40 \pm 9.01)$, AF $(57.58 \pm 0.94)$, and VF $(32.95 \pm$ $0.49)$, respectively. Among the forest, the activity of urease ( $\mu \mathrm{g} \mathrm{NH}_{3}-\mathrm{N} \mathrm{g}^{-1} \mathrm{~h}^{-1}$ ) was found to be significantly greater in MFC $(41.58 \pm 0.56)$ than PFC $(30.40 \pm 0.48)$ at $P<0.05$. Among cultivated lands, high urease activity $\left(\mu \mathrm{g} \mathrm{NH}_{3}-\mathrm{N} \mathrm{g}^{-1} \mathrm{~h}^{-1}\right)$ was evaluated under VF (38.34 \pm $0.39)$ as compared to AF (34.06 \pm 3.11$)$. However, the values were not significant among $\mathrm{AF}$ and $\mathrm{VF}(P>0.05)$. The acid phosphatases ( $\mu$ g hydrolyzed phenol $\mathrm{g}^{-1} \mathrm{~h}^{-1}$ ) was high under MFC $(1051.98 \pm 65.40)$ followed by PFC $(287.18 \pm 6.93)$, VF $(95.22 \pm 4.54)$, and AF (68.02 \pm 4.23), respectively. The activity of acid phosphatases was significantly different among forest land uses (MFC, PFC) $(P<0.05)$. However, no significant difference was determined under cultivated land uses $(\mathrm{AF}, \mathrm{VF})(P>$ 


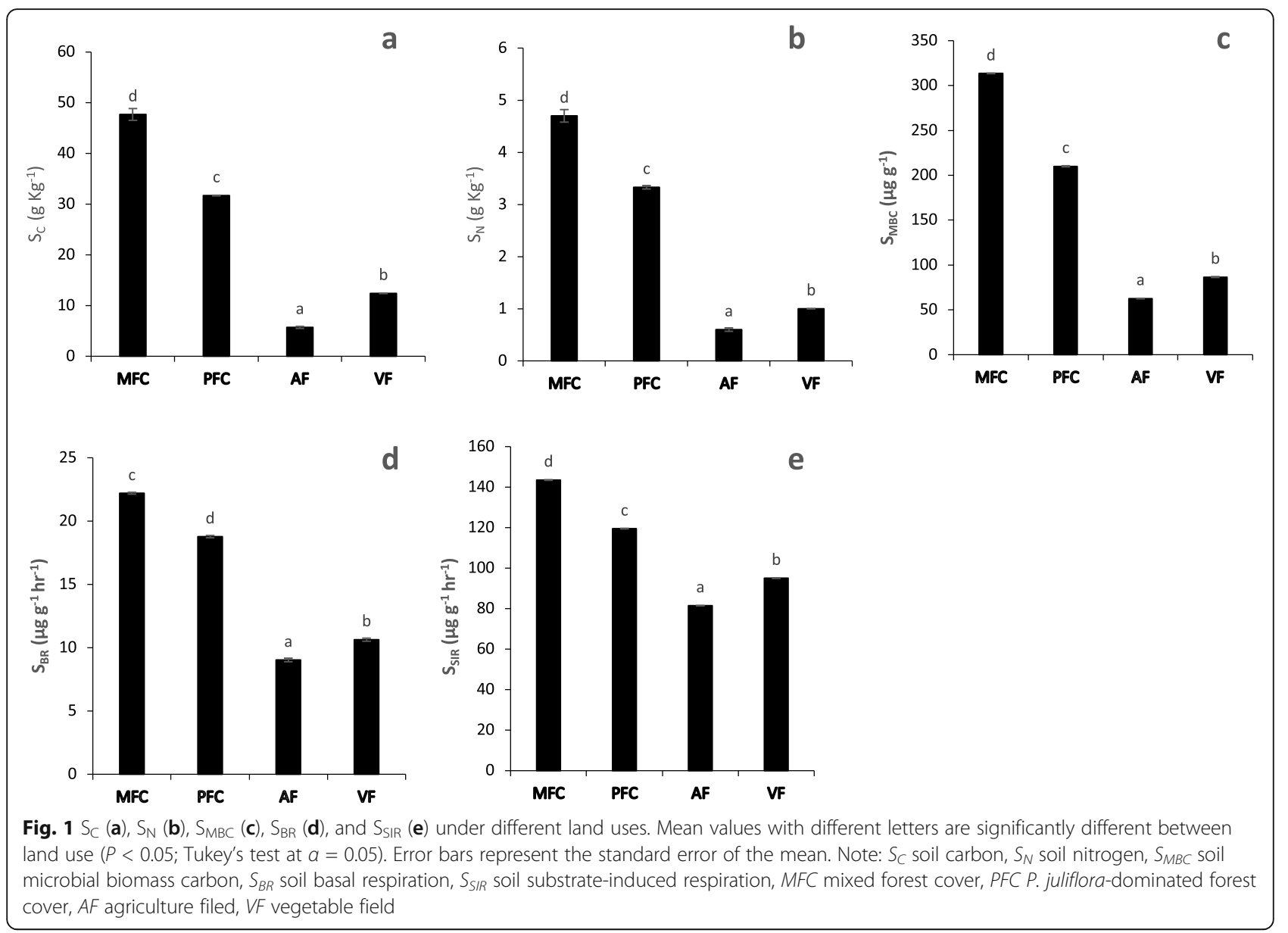

0.05). The activity of dehydrogenase was significantly

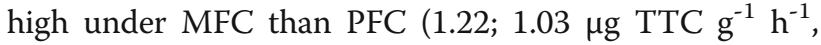
respectively) $(P<0.05)$. However, no dehydrogenase activity was detected under arable land uses (AF and VF).

Based on the combined data set for all land uses, Pearson's correlation analysis evaluated a significant correlation among the studied soil variables (Table 2). A significant strong positive correlation was found between $\mathrm{S}_{\mathrm{C}}, \mathrm{S}_{\mathrm{N}}, \mathrm{S}_{\mathrm{MBC}}, \mathrm{S}_{\mathrm{BR}}$, and $\mathrm{S}_{\mathrm{SIR}}(P<0.01)$. The positive correlation of $\beta$-glucosidase and dehydrogenase was observed with $\mathrm{S}_{\mathrm{C}}, \mathrm{S}_{\mathrm{N}}, \mathrm{S}_{\mathrm{MBC}}, \mathrm{S}_{\mathrm{BR}}$, and $\mathrm{S}_{\mathrm{SIR}}(P<0.05)$. Additionally, a significant positive correlation was found among $\mathrm{S}_{\mathrm{M}}$ and urease activity $(P<0.01)$. Further, the $\mathrm{qCO}_{2}$ showed a significant negative correlation with $\mathrm{S}_{\mathrm{C}}$, $\mathrm{S}_{\mathrm{BR}}$, and $\mathrm{S}_{\mathrm{SIR}}(P<0.01)$, and $\mathrm{S}_{\mathrm{N}}(P<0.05)$, respectively.

The principal component analysis (PCA) extracted three components with PC 1, PC 2, and PC 3 explained $71.38,19.55$, and $9.07 \%$ of the variance, respectively. For the biplot, PC 1 and PC 2 components were used, which together explained $90.34 \%$ of the variance. The PC 1 loadings were large and positive for $\mathrm{S}_{\mathrm{C}}, \mathrm{S}_{\mathrm{N}}, \mathrm{S}_{\mathrm{P}}, \mathrm{S}_{\mathrm{MBC}}$, $\mathrm{S}_{\mathrm{BR}}$, and $\mathrm{S}_{\mathrm{SIR}}$, and activity of $\beta$-glucosidase, dehydrogenase, and acid phosphatase, while negative for $\mathrm{qCO}_{2}$ and $\mathrm{S}_{\mathrm{MBC}} / \mathrm{S}_{\mathrm{C}}$ (Fig. 4). In PC 2, loadings were large and positive only for $\mathrm{S}_{\mathrm{C}} / \mathrm{S}_{\mathrm{N}}, \mathrm{S}_{\mathrm{M}}$, and urease activity in comparison with those in PC 1 . Among the land uses, PFC and MFC are closely associated with the variables of $S_{C}, S_{N}, S_{M B C}, S_{B R}$, and $S_{S I R}$, and enzyme activities. However, VF and AF are closely associated with $\mathrm{qCO}_{2}$ and $\mathrm{S}_{\mathrm{MBC}} / \mathrm{S}_{\mathrm{C}}$.

\section{Discussion}

$\mathrm{S}_{\mathrm{MBC}}$ indicates the size of the $\mathrm{S}_{\mathrm{C}}$ labile pool (Hanson et al. 2000) and is sensitive to land use conversions. The study reported a higher $\mathrm{S}_{\mathrm{MBC}}$ from forests (PFC, MFC) as compared with cultivated sites (AF, VF), with a significant reduction of $\sim 70-80 \%$. Regular tillage in cultivated land use often damages the soil aggregates and exposes the $\mathrm{S}_{\mathrm{OM}}$ for oxidation (Fang et al. 2014; Raiesi and Salek-Gilani 2020). Our results agree with the findings reported from previous studies indicating higher $\mathrm{S}_{\mathrm{MBC}}$ under natural forest than arable land use (Ananyeva et al. 2008; Zhao et al. 2012; Mganga and Kuzyakov 2014; Kooch et al. 2019; dos Santos et al. 

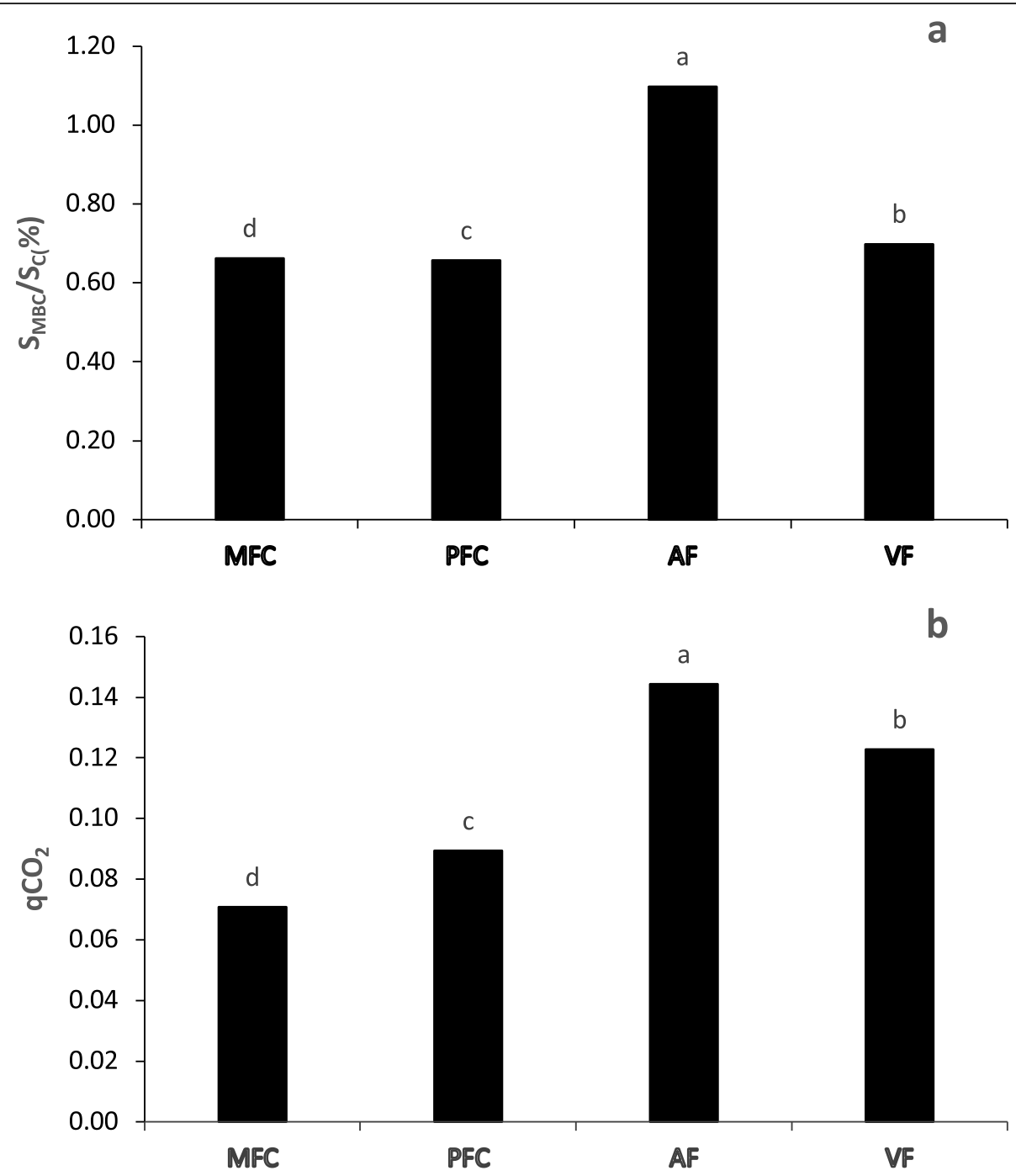

Fig. $2 \mathrm{~S}_{\mathrm{MBC}} / \mathrm{S}_{\mathrm{C}}(\mathbf{a})$ and $\mathrm{qCO}_{2}$ (b) under different land uses. Mean values with different letters are significantly different between land uses $(P<$ 0.05). Note: $S_{M B C} / S_{C}$ soil microbial biomass carbon to soil carbon ratio, $q_{C O}$ metabolic quotient, MFC mixed forest cover, PFC $P$. juliflora-dominated forest cover, AF agriculture filed, VF vegetable field

2019). The long-term accumulation of $\mathrm{S}_{\mathrm{OM}}$ input, $\mathrm{S}_{\mathrm{OM}}$ quality, and quantity determine the $\mathrm{S}_{\mathrm{MBC}}$ (Moore et al. 2000). It was evident in our study by the strong positive correlation of $S_{M B C}$ with $S_{C}$ and $S_{N}$.

Vegetation cover influences the quality and quantity of litter accumulation, therefore, affect $\mathrm{S}_{\mathrm{OM}}$ decomposition (Tiwari et al. 2019). The increased plant diversity in MFC favors plant rhizosphere by providing various substrates to soil microbes (dos Santos et al. 2019). Also, the varying quality of litter affects the $\mathrm{S}_{\mathrm{OM}}$ decomposition, which could explain low microbial activity in PFC as the leaves of $P$. juliflora has higher lignin content and does not degrade rapidly. In this study, high $S_{C}$ and $S_{N}$ contents were detected in sites presenting the greater plant diversity and vegetation cover. According to de
Medeiros et al. (2017), high tree density and diversity of dominant species in intermediate and late regenerative stages increase the root biomass, organic matter, litter content, and SOC in tropical dry forests of the semiarid Brazilian region.

The variability of the humic substrate also indicates the differences in $S_{B R}$ (heterotrophic respiration) and $\mathrm{S}_{\mathrm{SIR}}$ (potential respiration) among various land use/ cover types. The highest $S_{B R}$ and $S_{S I R}$ values were found in MFC, and the lowest were recorded under AF. Kooch et al. (2019) also reported a higher $S_{S I R}, S_{M B C}$, $\mathrm{S}_{\mathrm{BR}} / \mathrm{SOM}_{\mathrm{BC}}$ under natural forests and plantations as compared with agricultural sites. Higher aboveground and belowground biomass (Meena et al. 2020), fine root activity (Davidson et al. 2002), and litter content 


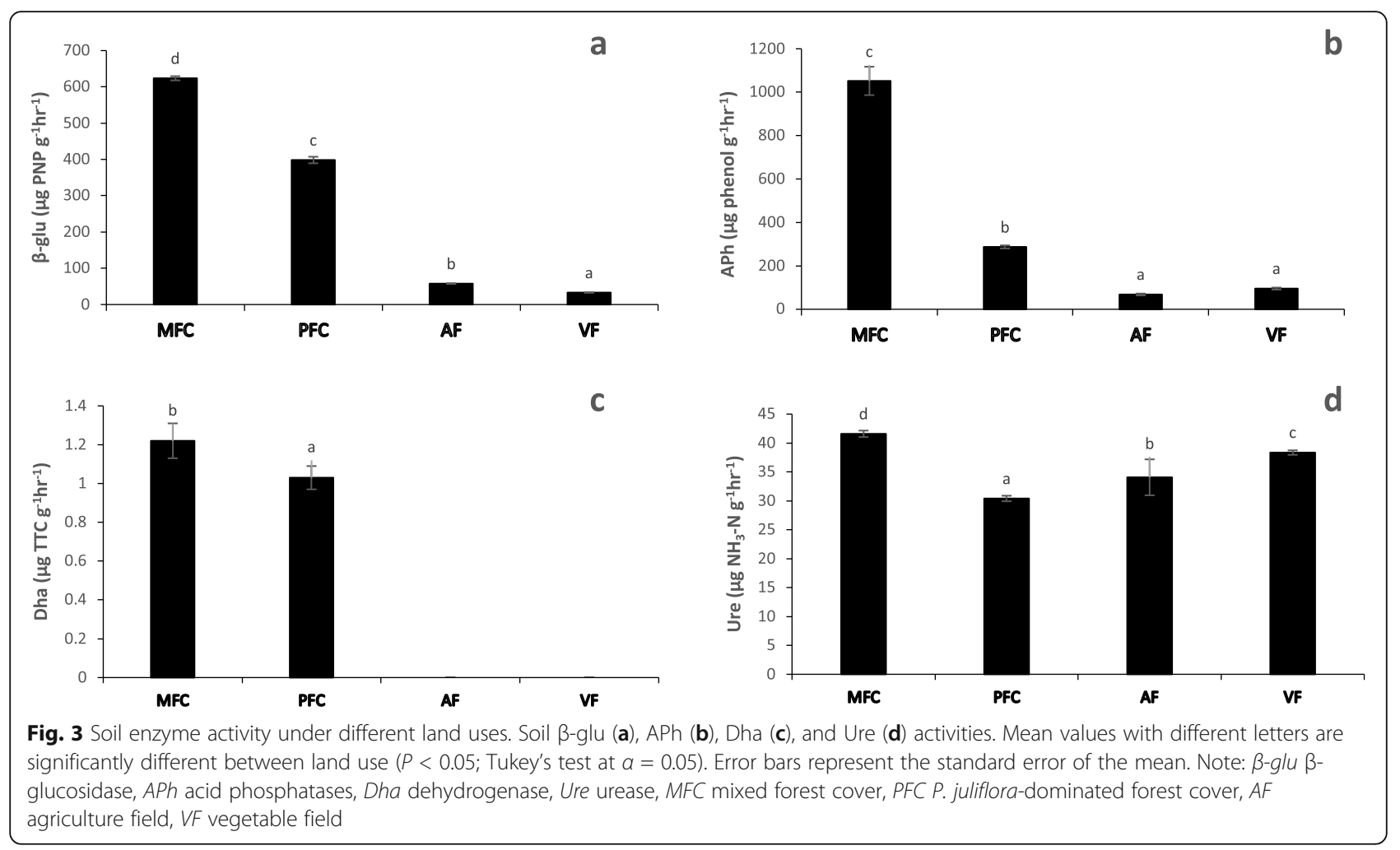

Table 2 Pearson correlation coefficients ( $r$ ) between soil physicochemical, microbial parameters, and enzyme activities among different land uses of a semiarid region of Delhi

\begin{tabular}{|c|c|c|c|c|c|c|c|c|c|c|c|c|c|c|}
\hline & $\mathrm{S}_{\mathrm{C}}$ & $\mathrm{S}_{\mathrm{N}}$ & $\mathrm{S}_{\mathrm{C}} / \mathrm{S}_{\mathrm{N}}$ & $S_{P}$ & $\mathrm{~S}_{\mathrm{M}}$ & $S_{M B C}$ & $\mathrm{~S}_{\mathrm{BR}}$ & $\mathrm{S}_{\mathrm{SIR}}$ & $\mathrm{S}_{\mathrm{MBC}} / \mathrm{S}_{\mathrm{C}}$ & $\mathrm{qCO}_{2}$ & $\beta$-glu & Dha & Ure & APh \\
\hline$S_{C}$ & 1 & $0.996^{* *}$ & -0.248 & 0.616 & 0.486 & $0.998 * *$ & $0.991^{* *}$ & $0.998^{* *}$ & -0.710 & $-0.990^{* *}$ & $0.984^{*}$ & $0.963^{*}$ & 0.348 & 0.919 \\
\hline$S_{N}$ & & 1 & -0.321 & 0.653 & 0.416 & $0.997^{* *}$ & $0.997^{* *}$ & $0.990^{* *}$ & -0.681 & $-0.983^{*}$ & $0.992^{* *}$ & $0.981^{*}$ & 0.275 & 0.899 \\
\hline$S_{C} / S_{N}$ & & & 1 & -0.301 & 0.446 & -0.295 & -0.325 & -0.186 & -0.354 & 0.160 & -0.414 & -0.444 & 0.495 & -0.198 \\
\hline$S_{P}$ & & & & 1 & -0.292 & 0.592 & 0.706 & 0.607 & -0.696 & -0.684 & 0.602 & 0.756 & -0.434 & 0.257 \\
\hline$S_{M}$ & & & & & 1 & 0.481 & 0.364 & 0.520 & -0.377 & -0.459 & 0.401 & 0.234 & $0.988^{* *}$ & 0.720 \\
\hline$S_{M B C}$ & & & & & & 1 & $0.989 * *$ & $0.993^{* *}$ & -0.665 & -0.979 & $0.992^{* *}$ & $0.964^{*}$ & 0.346 & 0.931 \\
\hline$S_{B R}$ & & & & & & & 1 & $0.984^{*}$ & -0.706 & $-0.986^{* *}$ & $0.985^{*}$ & $0.989^{* *}$ & 0.219 & 0.866 \\
\hline$S_{S I R}$ & & & & & & & & 1 & -0.744 & $-0.994^{* *}$ & $0.971^{*}$ & $0.948^{*}$ & 0.384 & 0.918 \\
\hline $\mathrm{S}_{\mathrm{MBC}} / \mathrm{S}_{\mathrm{C}}$ & & & & & & & & & 1 & 0.801 & -0.585 & -0.642 & -0.256 & -0.494 \\
\hline $\mathrm{qCO}_{2}$ & & & & & & & & & & 1 & -0.954 & -0.953 & -0.316 & -0.867 \\
\hline$\beta$-glu & & & & & & & & & & & 1 & $0.977^{*}$ & 0.266 & 0.914 \\
\hline Dha & & & & & & & & & & & & 1 & 0.086 & 0.811 \\
\hline Ure & & & & & & & & & & & & & 1 & 0.622 \\
\hline APh & & & & & & & & & & & & & & 1 \\
\hline
\end{tabular}

$S_{C}$ soil carbon, $S_{N}$ soil nitrogen, $S_{P}$ soil phosphorus, $S_{M}$ soil moisture, $S_{M B C}$ soil microbial biomass carbon, $S_{B R}$ soil basal respiration, $S_{S / R}$ soil substrate-induced respiration, $S_{M B C} / S_{C}$ soil microbial biomass carbon to soil carbon ratio, $q C_{2}$ metabolic quotient, $S_{C} / S_{N}$ soil carbon to soil nitrogen ratio, $\beta$-glu $\beta$-glucosidase, $A P h$ acid phosphatases, Dha dehydrogenase, Ure urease

* Correlation is significant at the 0.05 level

** Correlation is significant at the 0.01 level 


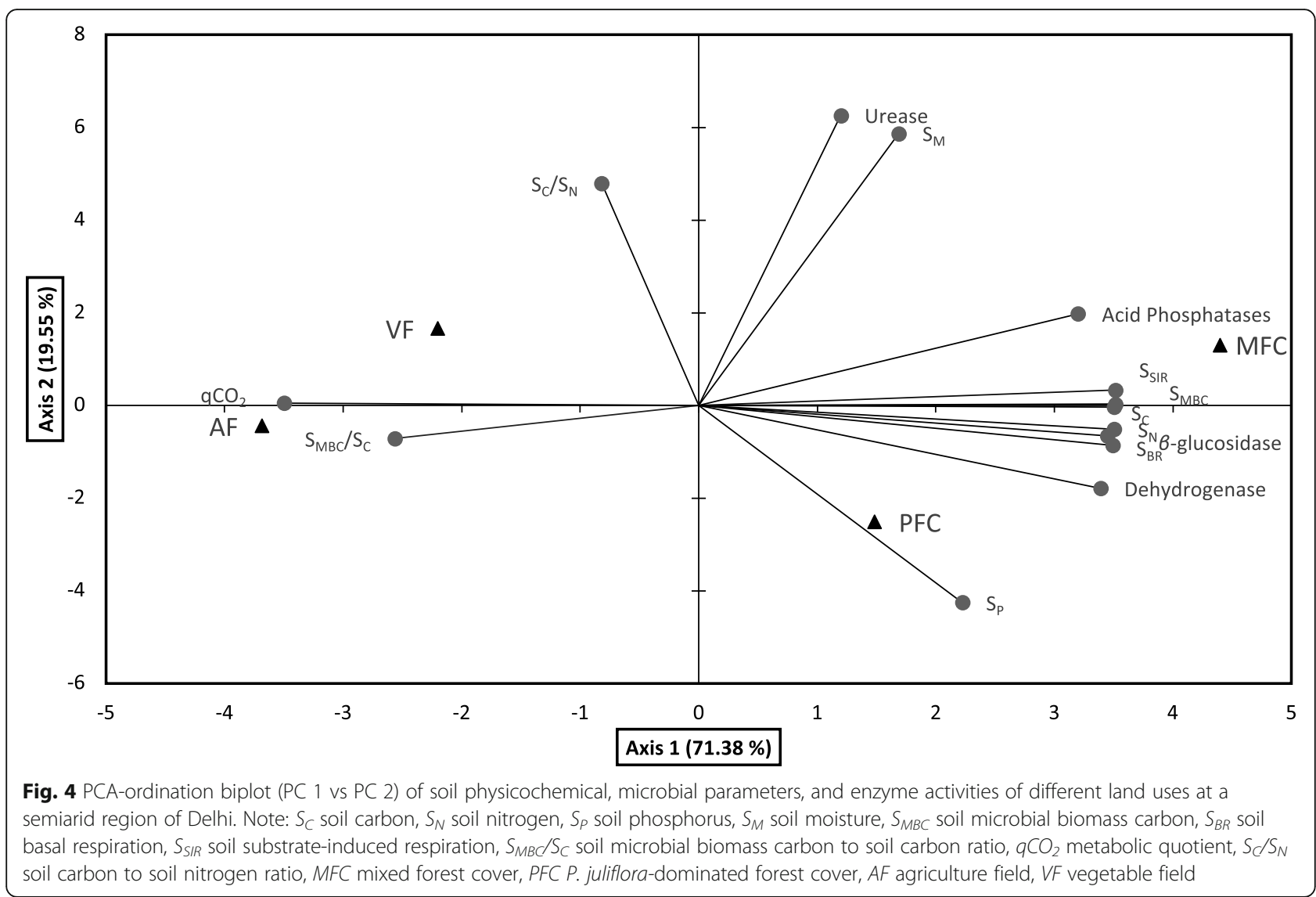

(Chodak and Niklinska 2010) in forests maintain the $S_{C}$ for a longer period. Parallel to the previous studies, the $\mathrm{qCO}_{2}$ or metabolic quotient which measures the ecophysiological state of the soil microbial community was found to be largest for AF (Ananyeva et al. 2008; Cheng et al. 2013; Fang et al. 2014; Kooch et al. 2019). The strong negative correlation of $\mathrm{qCO}_{2}$ with $\mathrm{SOM}_{\mathrm{BC}}$, $\mathrm{S}_{\mathrm{BR}}$, and $\mathrm{S}_{\mathrm{SIR}}$ indicates that reduced substrate carbon supply declines the microbial biomass size, activity, and microbial efficiency for substrate carbon utilization (Wardle and Ghani 1995; Six et al. 2006; Yang et al. 2010). Under a disturbed ecosystem, the strong competition for available carbon substrate may favor microbes that use more carbon energy in maintenance than growth (Islam and Weil 2000). Therefore, in cultivated soils, the microbial communities are more stressed and needed a regular supply of carbon sources to maintain their activity (Singh et al. 2018).

In semiarid ecosystems, $\mathrm{S}_{\mathrm{OM}}$ is considered as the main controlling factor for soil microbial activity and respiration (Zhang et al. 2013; Bao et al. 2016; Meena et al. 2020). Among the cultivated sites, a comparatively higher $S_{M}$ and nutrient content $\left(S_{C}, S_{N}, S_{P}\right)$ in VF could explain the greater respiration values under $\mathrm{VF}$ than $\mathrm{AF}$ (Giesler et al. 2012; Tardy et al. 2014).
The $\mathrm{S}_{\mathrm{MBC}} / \mathrm{S}_{\mathrm{C}}$ ratio or $\mathrm{MQ}$ has been widely used as an indicator of soil quality and future changes in $\mathrm{S}_{\mathrm{OM}}$ (Sparling et al. 1992). It also reflects the contribution of the $S_{M B C}$ to $S_{C}$ and can be used as a sensitive measure of soil health under different land use management systems (Anderson and Domsch 1989). The previous studies have reported a high MQ in the forest as compared with cultivated land (Dinesh et al. 2004; Kooch et al. 2019). Contrastingly, in our study, the higher MQ in AF could be related to lower $\mathrm{S}_{\mathrm{C}}$ owing to a larger proportion of the $S_{M B C}$ to total $S_{C}$ (Araújo et al. 2013). Hence, the soils in the cultivated lands are more sensitive to the change related to land use and management (Sampaio et al. 2008).

\section{Soil enzyme activity}

Soil enzyme activity is influenced by the soil characteristics related to nutrient availability, soil microbial activity, and land use management processes which modified the potential soil enzyme-mediated substrate catalysis (Kandeler et al. 1996). In this study, the activity of all the enzymes was higher under MFC. With the low level of anthropogenic influence under MFC, the soils were covered with high litter content and added greater $\mathrm{S}_{\mathrm{OM}}$. This suggests that the enzyme activities are governed by 
the availability of carbon sources and $\mathrm{S}_{\mathrm{OM}}$ decomposition. The intensive management practices under $\mathrm{AF}$ and VF constantly disturb the soil and regular removal of litter layer restricted the supply of substrate for microbes, thereby reduces the enzyme activities. Kotroczó et al. (2014) reported that under different treatments of detritus input and removal, the enzyme activities were more influenced by root activity rather than aboveground litter availability. In this case, the higher activity of root and rhizosphere in natural forests increased the enzyme activities. Previous studies reported a reduction in soil enzyme activities following the conversion of natural forests into cultivated lands (Araújo et al. 2013; Raiesi and Beheshti 2015; Vinhal-Freitas et al. 2017; Silva et al. 2019).

Urease regulates the $S_{N}$ transformation and is involved in the hydrolysis of urea into ammonia and $\mathrm{CO}_{2}$ (Kong et al. 2008). The urease activity is influenced by various soil properties including $\mathrm{pH}$, soil nutrient supply, $\mathrm{S}_{\mathrm{N}}$, $\mathrm{S}_{\mathrm{MBN}}$, and $\mathrm{N}$ fertilizers (Moghimian et al. 2017). In this study, the highest urease activity was evaluated in MFC than all other land use/cover types. Our results were similar to previous findings indicating greater urease activity under natural forest than cultivated area, and indicating that the availability of fresh $\mathrm{S}_{\mathrm{OM}}$ for microbial decomposition enhances the microbial activity in forest soil and increases the enzyme activity (de Medeiros et al. 2015; Vinhal-Freitas et al. 2017). Contrastingly, in cultivated fields (i.e., $\mathrm{AF}$ and $\mathrm{VF}$ ), high urease activity was found despite low values of $\mathrm{S}_{\mathrm{C}}$ and $\mathrm{S}_{\mathrm{N}}$. This can be explained by the regular supply of urea fertilizer to the field. Also, a strong positive correlation of urease activity with $\mathrm{S}_{\mathrm{M}}$ supported its increased activity in VF (Zeng et al. 2009).

Dehydrogenase activity in soil serves as an indicator of the microbiological redox system and microbial oxidative activities in soil (Casida Jr et al. 1964). It indicates the respiratory activity of the soil and can be used as a measure of microbial activity in semiarid climates (García et al. 1994; Bastida et al. 2006). In this case, no dehydrogenase activity was detected under cultivated sites (i.e., AF and VF). The reduced content of labile carbon and $\mathrm{S}_{\mathrm{C}}$ are suggested to decrease the activity (Bastida et al. 2006). Bonanomi et al. (2011) reported a reduction by $84 \%$ in dehydrogenase activity in a low-input management regime as compared with the high-input management regime. de Medeiros et al. (2015) detected the dehydrogenase activity in soils under different intercropping areas found the lowest activity in Maninot esculenta, Cajanus cajan, Vignia unguiculata monoculture. The study reported that soil disaggregation due to short cropping cycle and weeding along with low vegetation cover attributed to reduced enzyme activity. Further, in dry climate conditions the abiotic stress to microbial activity due to high temperature and low $S_{M}$ influence the organic matter oxidation by dehydrogenase ( $\mathrm{Li}$ and Sarah 2003).

In addition, $\beta$-glucosidase activity in soil is linked to the release of carbohydrates in soil, which provides a major substrate for soil microorganisms. The positive correlation of the $S_{C}$ and $S_{M B C}$ with $\beta$-glucosidase activity indicated that $\mathrm{S}_{\mathrm{OM}}$ content is the major factor in its activity (Vinhal-Freitas et al. 2017). Corroborating with our results, Silva et al. (2019) evaluated $\beta$-glucosidase activity under tropical dry native forest, protected area, scrub, and maize cultivated area; reported reduced activity under the cultivated field; and suggested a closed linking of $\beta$-glucosidase with $\mathrm{SOC}$ and $\mathrm{S}_{\mathrm{OM}}$ content. de Medeiros et al. (2015) demonstrated similar $\beta$ glucosidase activity among tropical dry forest and intercropping soils of Brazil with less aggressive management practices. The study also reported a reduced activity under semiarid ecosystems attributed due to the slow decomposition of $\mathrm{S}_{\mathrm{MBC}}$.

Similarly, the acid phosphatase activity was also higher under forests as compared to cultivated land use. Further, a nonsignificant yet positive correlation of $\mathrm{S}_{\mathrm{C}}$ and $\mathrm{S}_{\mathrm{MBC}}$ with acid phosphatase activity indicates their importance in regulating its activity (Hendriksen et al. 2016; Acosta-Martínez et al. 2018). Similar to this study, Silva et al. (2019) found no correlation between $S_{P}$ and acid phosphatase. This confirms that the activity of acid phosphatase activity is also influenced by soil $\mathrm{pH}$, nutrients, $\mathrm{S}_{\mathrm{C}}, \mathrm{S}_{\mathrm{N}}, \mathrm{S}_{\mathrm{P}}, \mathrm{S}_{\mathrm{OM}}$ quality and quantity, microbial community structure, $\mathrm{S}_{\mathrm{M}}$, and soil temperature (Hendriksen et al. 2016; Maharajan et al. 2017; Moghimian et al. 2017). Raiesi and Beheshti (2015) indicated that soil $\mathrm{pH}$ is the main regulator of acid phosphatase activity, and narrow $\mathrm{pH}$ ranges attributed to no significant changes after natural forest conversions in Iran.

\section{Factors affecting microbial and enzyme activities}

The PCA evaluated the dissimilarities in soil parameters (i.e., $S_{M}, S_{P}, S_{C}, S_{N}, S_{M B C}, S_{B R}, S_{S I R}, S_{M B C} / S_{C}, q C O_{2}, \beta-$ glucosidases, ureases, acid phosphatase, and dehydrogenase activity) among the four land uses. The cultivated (i.e., AF and VF) appeared to be different from the respective forest analogs (i.e., PFC and MFC). The clustering of $S_{C}, S_{N}, S_{M B C}, S_{B R}, S_{S I R}, \beta$-glucosidase, dehydrogenase, and acid phosphatases nearby PFC and MFC indicate the critical role of $\mathrm{S}_{\mathrm{OM}}$ in controlling the microbial and enzyme activities (Cheng et al. 2013). High $\mathrm{S}_{\mathrm{OM}}$ in forest land use due to dense vegetation, deep rooting system, and greater amount of litter favors microbial activity (Tiwari et al. 2019). The $S_{M}$ often considered as the key factor in controlling soil microbial functions. Fang et al. (2014) and Tiwari et al. (2019) suggested slower decomposition and microbial activity in 
cultivated land uses as results of low $\mathrm{S}_{\mathrm{M}}$ content. Additionally, the clustering of urease with $S_{M}$ is similar to various findings, suggesting a significant role of $S_{M}$ in enhancing urease activity in soil (Sahrawat 1983). Further, clustering of $\mathrm{qCO}_{2}$ and $\mathrm{S}_{\mathrm{MBC}} / \mathrm{S}_{\mathrm{C}}$ near the $\mathrm{AF}$ and VF suggest a reduced efficiency of microbes to utilize substrate carbon in cultivated lands (Araújo et al. 2014) as compared with more recalcitrant carbon in forest analogs.

\section{Conclusion}

Our study suggests that land use/cover changes and management practices influence the soil microbial parameters and enzyme activity in a semiarid region. Low $\mathrm{S}_{\mathrm{OM}}$ in cultivated lands (AF, VF) limits the soil microbial activity thereby reducing $\mathrm{S}_{\mathrm{MBC}}, \mathrm{S}_{\mathrm{BR}}$, and $\mathrm{S}_{\mathrm{SIR}}$. In comparison, an increased amount of substrate quantity and quality in the native forest land uses enhances the $\mathrm{S}_{\mathrm{OM}}$ content favoring high microbial activity. The variation in plant species composition, $\mathrm{S}_{\mathrm{M}}$ content, and litter quality within the land use further affect microbial activity. Among the two forests, the higher plant diversity under MFC had significantly enhanced the $S_{C}, S_{N}, S_{M B C}, S_{B R}$, $\mathrm{S}_{\mathrm{SIR}}$, and enzyme activity as compared with the PFC, while among the two cultivated land uses, under AF, the intensive management practices including tillage, fallow periods, application of fertilizers, and low $S_{M}$ had drastically reduced the $S_{\mathrm{OM}}$ quantity and quality and hence, the microbial and enzyme activity. The strong positive correlation of soil parameters $\left(\mathrm{S}_{\mathrm{C}}, \mathrm{S}_{\mathrm{N}}\right)$ with microbial activities $\left(\mathrm{S}_{\mathrm{MBC}}, \mathrm{S}_{\mathrm{BR}}, \mathrm{S}_{\mathrm{SIR}}\right)$ and soil enzymes ( $\beta$-glucosidase, acid phosphatase, and dehydrogenase) further suggests the critical role of $\mathrm{S}_{\mathrm{OM}}$ and soil nutrient in maintaining soil fertility. A higher $\mathrm{S}_{\mathrm{MBC}} / \mathrm{S}_{\mathrm{C}}$ and $\mathrm{qCO}_{2}$ under $\mathrm{AF}$ suggest that cultivated sites are more sensitive to the $\mathrm{S}_{\mathrm{C}}$ changes in topsoil layers. Anthropogenic interventions in cultivated lands alter the soil structure and physicochemical parameters, thereby affecting the soil microbial and enzyme activity as strongly suggested from our results. Therefore, the soil microbiological parameters are potential indicators to study soil response and $\mathrm{S}_{\mathrm{C}} \mathrm{dy}-$ namics following land use conversions and management practices. The implication of such studies is even more significant in climate-stressed semiarid ecosystems, where effective land management practices in cultivated lands and restoration of forest ecosystems enhance $S_{\mathrm{OM}}$ and microbial functions.

\footnotetext{
Abbreviations

AF: Agriculture field; MF: Mixed forest cover; $\mathrm{qCO}_{2}$ : Metabolic quotient; PCA: Principal component analysis; PFC: Prosopis juliflora-dominated forest cover; $S_{B R}$ : Soil basal respiration; $S_{C}$ : Soil carbon; $S_{C} / S_{N}$ : Soil carbon to soil nitrogen ratio; $\mathrm{S}_{M}$ : Soil moisture; $\mathrm{S}_{\mathrm{MBC}}$ : Soil microbial biomass carbon; $\mathrm{S}_{\mathrm{MBC}}$ $S_{C}$ : Soil microbial biomass carbon to soil carbon ratio; $S_{M B N}$ : Soil microbial biomass nitrogen; $\mathrm{S}_{\mathrm{N}}$ : Soil nitrogen; $\mathrm{S}_{\mathrm{O}}$ : Soil organic matter; $\mathrm{S}_{\mathrm{p}}$ : Soil phosphorus; $S_{S I R}$ : Soil substrate-induced respiration; VF: Vegetable field
}

\section{Acknowledgements}

We thank the Council of Scientific and Industrial Research (CSIR; Ref No. 2012/2009(ii) EU-IV). We also thank the University of Delhi for providing Research and Development and for providing grant for doctoral research program.

\section{Authors' contributions}

AM proposed the idea and conducted the field sampling, data collection, laboratory analysis, data interpretation, and manuscript writing. KSR guided the study, interpreted the results, and critically reviewed the idea. All authors read and approved the final manuscript.

\section{Availability of data and materials}

The datasets used and/or analyzed during the current study are available from the corresponding author on reasonable request.

Ethics approval and consent to participate

Not applicable

\section{Consent for publication}

Not applicable

\section{Competing interests}

The authors declare no competing interests.

\section{Author details}

${ }^{1}$ Department of Botany, University of Rajasthan, Jaipur, Rajasthan 302004 , India. ${ }^{2}$ Natural Resource Management Laboratory, Department of Botany, University of Delhi, North Campus, Delhi 110007, India.

Received: 25 July 2020 Accepted: 10 February 2021

Published online: 01 March 2021

\section{References}

Acosta-Martínez V, Cano A, Johnson J (2018) Simultaneous determination of multiple soil enzyme activities for soil health-biogeochemical indices. Appl Soil Ecol 126:121-128

Acosta-Martínez V, Mikha MM, Vigil MF (2007) Microbial communities and enzyme activities in soils under alternative crop rotations compared to wheat-fallow for the Central Great Plains. Appl Soil Ecol 37(1-2):41-52

Allen SE, Grimshaw HM, Parkinson JA, Quarmby C (1974) Chemical analysis of ecological materials. Blackwell Scientific, Oxford

Ananyeva ND, Susyana EA, Chernova OV, Wirth S (2008) Microbial respiration activities of soils from different climatic regions of European Russia. Eur J Soil Biol 44(2):147-157

Anderson JPE, Domsch KH (1978) A physiological method for the quantitative measurement of microbial biomass in soils. Soil Biol Biochem 10(3):215-221

Anderson TH, Domsch KH (1989) Ratios of microbial biomass carbon to total organic-C in arable soils. Soil Biol Biochem 21(4):471-479

Anderson TH, Domsch KH (1990) Application of eco-physiological quotients $\left(\mathrm{qCO}_{2}\right.$ and $\left.\mathrm{qD}\right)$ on microbial biomasses from soils of different cropping histories. Soil Biol Biochem 22(2):251-255

Araújo ASF, Borges CD, Tsai SM, Cesarz S, Eisenhauer N (2014) Soil bacterial diversity in degraded and restored lands of Northeast Brazil. Antonie Van Leeuwenhoek 106(5):891-899

Araújo ASF, Cesarz S, Leite LFC, Borges CD, Tsai SM, Eisenhauer N (2013) Soil microbial properties and temporal stability in degraded and restored lands of Northeast Brazil. Soil Biol Biochem 66:175-181

Bao X, Zhu X, Chang X, Wang S, Xu B, Luo C, Zhang Z, Wang Q, Rui Y, Cui X (2016) Effects of soil temperature and moisture on soil respiration on the Tibetan plateau. PLoS One 11(10):e0165212

Bastida F, Moreno JL, Hernández T, García C (2007) The long-term effects of the management of a forest soil on its carbon content, microbial biomass and activity under a semi-arid climate. Appl Soil Ecol 37(1-2):53-62

Bastida F, Moreno JL, Hernandéz TH, García C (2006) Microbiological degradation index of soils in a semiarid climate. Soil Biol Biochem 38:3463-3473

Bonanomi G, D'Ascoli R, Antignani V, Capodilupo M, Cozzolino L, Marzaioli R, Puopolo G, Rutigliano FA, Scelza R, Scotti R, Rao MA, Zoina A (2011) Assessing soil quality under intensive cultivation and tree orchards in Southern Italy. Appl Soil Ecol 47(3):184-194 
Casida LE Jr, Klein DA, Santoro T (1964) Soil dehydrogenase activity. Soil Sci 98 : $371-376$

Celik I (2005) Land-use effects on organic matter and physical properties of soil in a southern Mediterranean highland of Turkey. Soil Tillage Res 83(2):270-277

Census (2011) Census of India 2011. Registrar General of India, Ministry of Home Affair, Government of India. Available at: https://www.census2011.co.in/ census/state/delhi

Champion HG, Seth SK (1968) A revised survey of the forest types of India. Govt. of India Publications, New Delhi

Cheng F, Peng X, Zhao P, Yuan J, Zhong C, Cheng Y, Cui C, Zhang S (2013) Soil microbial biomass, basal respiration and enzyme activity of main forest types in the Qinling Mountains. PLoS One 8(6):67353

Chibbar RK (1985) Soils of Delhi and their management. In: Biswas BC, Yadav DS, Maheshwari S (eds) Soils of India and their management. Fertiliser Association of India, New Delhi, pp 72-86

Chodak M, Niklinska M (2010) Effect of texture and tree species on microbial properties of mine soils. Appl Soil Ecol 46(2):268-275

Cookson WR, Osman M, Marschner P, Abaye DA, Clark I, Murphy DV, Stockdale EA, Watson CA (2007) Controls on soil nitrogen cycling and microbial community composition across land use and incubation temperature. Soil Biol Biochem 39(3):744-756

Davidson EA, Savage K, Verchot LV, Navarro R (2002) Minimizing artifacts and biases in chamber-based measurements of soil respiration. Agric For Meteorol 113(1-4):21-37

Dawson JJC, Smith P (2007) Carbon losses from soil and its consequences for land use management. Sci Total Environ 382(2-3):165-190

de Medeiros EV, Duda GP, dos Santos LAR, Lima JRS (2017) Soil organic carbon, microbial biomass and enzyme activities responses to natural regeneration in a tropical dry region in Northeast Brazil. Catena 151:137-146

de Medeiros EV, Notaro KA, de Barros JA, Moraes WS, Silva AO, Moreira KA (2015) Absolute and specific enzymatic activities of sandy entisol from tropical dry forest, monoculture and intercropping areas. Soil Tillage Res 145:208-215

Dinesh R, Chaudhuri SG, Sheeja TE (2004) Soil biochemical and microbial indices in wet tropical forests: Effects of deforestation and cultivation. J Plant Nutr Soil Sci 167(1):24-32

dos Santos UJ, de Medeiros EV, Duda GP, Marques MC, de Souza ES, Brossard M, Hammecker C (2019) Land use changes the soil carbon stocks, microbial biomass and fatty acid methyl ester (FAME) in Brazilian semiarid area. Arch Agron Soil Sci 65(6):755-769

Eivazi F, Tabatabai MA (1988) Glucosidases and galactosidases in soils. Soil Biol Biochem 20:601-606

FSI (2017) Forest and tree resources in states and union territories, State of forest report - Delhi. Forest Survey of India, Ministry of Environment and Forests, Government of India, Dehradun

García C, Hernández T, Costa F (1994) Microbial activity in soils under Mediterranean environmental conditions. Soil Biol Biochem 26(9):1185-91

Giesler R, Esberg C, Lagerström A, Graae BJ (2012) Phosphorus availability and microbial respiration across different tundra vegetation types. Biogeochemistry 108:429-45

Goenster S, Gründler C, Buerkert A, Joergensen RG (2017) Soil microbial indicators across land use types in the river oasis Bulgan sum center, Western Mongolia. Ecol Indic 76:111-118

Hanson PJ, Edwards NT, Garten CT, Andrews JA (2000) Separating root and soil microbial contributions to soil respiration: a review of methods and observations. Biogeochemistry 48:115-46

Hendriksen N, Creamer R, Stone D, Winding A (2016) Soil exo-enzyme activities across Europe - the influence of climate, land-use and soil properties. Appl Soil Ecol 97:44-48

Huang J, Song C (2010) Effects of land use on soil water soluble organic C and microbial biomass C concentrations in the Sanjiang Plain in Northeast China. Acta Agr Scand BSP 60(2):182-188

Isermayer H (1952) Eine einpache methode zur bestimmung der pflanzenatmung und der karbonate in boden, Z. Pflanzenernähr. Düng Bodenk 56:26-28

Islam KR, Weil RR (2000) Land use effects on soil quality in a tropical forest ecosystem of Bangladesh. Agric Ecosyst Environ 79(1):9-16

Jain M, Dawa D, Mehta R, Dimri AP, Pandit MK (2016) Monitoring land use change and its drivers in Delhi, India using multi-temporal satellite data. Model Earth Syst Environ 2(19):1-19

Kabiri V, Raiesi F, Ghazavi MA (2016) Tillage effects on soil microbial biomass, SOM mineralization and enzyme activity in a semi-arid Calcixerepts. Agric Ecosyst Environ 232:73-84
Kandeler E, Kampichler C, Horak O (1996) Influence of heavy metals on the functional diversity of soil microbial communities. Biol Fertil Soils 23:299-306

Kong CH, Wang P, Zhao H, Xu XH, Zhu YD (2008) Impact of allelochemical exuded from allelopathic rice on soil microbial community. Soil Biol Biochem 40(7):1862-1869

Kooch Y, Ehsani S, Akbarinia M (2019) Stoichiometry of microbial indicators shows clearly more soil responses to land cover changes than absolute microbial activities. Ecol Eng 131:99-106

Kooch Y, Tavakoli M, Akbarinia M (2018) Tree species could have substantial consequences on topsoil fauna: a feedback of land degradation/restoration. Eur J For Res 137:793-805

Kotroczó Z, Veres Z, Fekete I, Krakomperger Z, Tóth JA, Lajtha K, Tóthmérész B (2014) Soil enzyme activity in response to long-term organic matter manipulation. Soil Biol Biochem 70:237-243

Kumar M, Ghosal N (2017) Impact of land-use change on soil microbial community composition and organic carbon content in the dry tropics. Pedosphere 27(5):974-977

Lacerda-Júnior GV, Noronha MF, Cabral L, Delforno TP, de Sousa STP, FernandesJúnior PI, Melo IS, Oliveira VM (2019) Land use and seasonal effects on the soil microbiome of a Brazilian dry forest. Front Microbiol 10:648

Li X, Sarah P (2003) Enzyme activities along a climatic transect in the Judean Desert. Catena 53:349-363

Maharajan M, Sanaullah M, Razavi BS, Kuzyakov Y (2017) Effect of land use and management practices on microbial biomass and enzyme activities in subtropical top- and sub-soils. Appl Soil Ecol 113:22-28

Meena A, Bidalia A, Hanief M, Dinakaran J, Rao KS (2019) Assessment of aboveand belowground carbon pools in a semi-arid forest ecosystem of Delhi, India. Ecol Process 8:8

Meena A, Hanief M, Bidalia A, Dinakaran J, Rao KS (2016) Structure, composition and diversity of tree strata of semi-arid forest community in Delhi, India. Phytomorphology 66(3-4):95-102

Meena A, Hanief M, Dinakaran J, Rao KS (2020) Soil moisture controls the spatiotemporal pattern of soil respiration under different land use systems in a semi-arid ecosystem of Delhi, India. Ecol Process 9:15

Mganga KZ, Kuzyakov Y (2014) Glucose decomposition and its incorporation into soil microbial biomass depending on land use in Mt. Kilimanjaro ecosystems. Eur J Soil Biol 62:74-82

Moghimian N, Hosseini SM, Kooch Y, Darki BZ (2017) Impacts of changes in land use/cover on soil microbial and enzyme activity. Catena 157:407-414

Moore JM, Klose S, Tabatabai MA (2000) Soil microbial biomass carbon and nitrogen as affected by cropping systems. Biol Fertil Soils 31:200-210

Nielsen UN, Ball BA (2015) Impacts of altered precipitation regimes on soil communities and biogeochemistry in arid and semi-arid ecosystems. Glob Chang Biol 21:1407-1421

Notaro KA, Medeiros EV, Duda GP, Silva AO, Moura PM (2014) Agroforestry systems, nutrients in litter and microbial activity in soils cultivated with coffee at high altitude. Sci Agric 71(2):87-95

Pandey D, Agrawal M, Bohra JS (2014) Effects of conventional tillage and no tillage permutations on extracellular soil enzyme activities and microbial biomass under rice cultivation. Soil Tillage Res 136:51-60

Pickett STA, Cadenasso ML, Grove JM, Nilon CH, Pouyat RV, Zipperer WC Costanza R (2001) Urban ecological systems: linking terrestrial, ecological, physical, and socioeconomic components of metropolitan areas. Annu Rev Ecol Syst 32:127-157

Rai PK, Rai A, Singh S (2018) Change in soil microbial biomass along a rural-urban gradient in Varanasi (U.P., India). Geol Ecol Land 2(1):15-21

Raiesi F, Beheshti A (2014) Soil specific enzyme activity shows more clearly soil responses to paddy rice cultivation than absolute enzyme activity in primary forests of northwest Iran. Appl Soil Ecol 75:63-70

Raiesi F, Beheshti A (2015) Microbiological indicators of soil quality and degradation following conversion of native forests to continuous croplands. Ecol Indic 50:173-185

Raiesi F, Salek-Gilani S (2020) Development of a soil quality index for characterizing effects of land-use changes on degradation and ecological restoration of rangeland soils in a semi-arid ecosystem. Land Degrad Dev 31(12):1533-1544

Sahrawat KL (1983) Relationships between soil urease activity and other properties of some tropical wetland rice soils. Nutr Cycl Agroecosyst 4(2):145-150

Sampaio DB, Araújo ASF, Santos VB (2008) Evaluation of biological indicators of soil quality under conventional and organic fruit farming system. Ciênc Agrotec 32(2):353-359 
Schneider K, Turrión MB, Gallardo JF (2000) Modified method for measuring acid phosphatase activities in forest soils with high organic matter content. Commun Soil Sci Plant Anal 31(19-20):3077-3088

Silva ÉO, de Medeiros EV, Duda GP, Junior MAL, Brossard M, de Oliveira JB, dos Santos UJ, Hammecker C (2019) Seasonal effect of land use type on soil absolute and specific enzyme activities in a Brazilian semi-arid region. Catena 172:397-407

Singh MK, Ghoshal N (2014) Variation in soil microbial biomass in the dry tropics impact of land-use change. Soil Res 52(3):299-306

Singh R, Bhardwaj DR, Pala NA, Kaushal R, Rajput BS (2018) Soil microbial characteristics in sub-tropical agro-ecosystems of North Western Himalaya. Curr Sci 115(10):1956-1959

Sinha GN (2014) An introduction to the Delhi Ridge. Department of Forests and Wildlife. Govt. of NCT of Delhi, New Delhi, pp Xxiv-154

Six J, Frey S, Thiet RK, Batten KM (2006) Bacterial and fungal contributions to carbon sequestration in agroecosystems. Soil Sci Soc Am J 70:555-569

Smith JL, Paul EA (1995) The significance of soil microbial biomass estimations. In: Lefroy RDB, Blair GJ, Craswell ET (eds) Soil Organic Matter Management for Sustainable Agriculture. Australian Center for International Agricultural Research, Canberra, pp 357-396

Sousa F, Ferreira T, Mendonça E, Romero R, Oliveira J (2012) Carbon and nitrogen in degraded Brazilian semi-arid soils undergoing desertification. Agric Ecosyst Environ 148:11-21

Sparling GP, Shepherd TG, Kettles HA (1992) Changes in soil organic C, microbial $C$ and aggregate stability under continuous maize and cereal cropping, and after restoration to pasture in soils from the Manawatu region, New Zealand. Soil Tillage Res 24:225-241

Tardy V, Mathieu O, Lévêque J, Terrat S, Chabbi A, Lemanceau P, Ranjard L, Maron PA (2014) Stability of soil microbial structure and activity depends on microbial diversity. Environ Microbiol Rep 6(2):173-183

Thalmann A (1968) Zur Metodik der Bestimmung der De-hydrogenaseaktivität im Boden mittels Triphenyltetrazo-liumchlorid (TTC). Landwirtsch Forsch 21:24958

Thapa VR, Ghimire R, Mikha MM, Idowu OJ, Marsalis MA (2018) Land use effects on soil health in semiarid drylands. Agric Environ Lett 3(1):1-5

Tiwari S, Singh C, Boudh S, Rai PK, Gupta VK, Singh JS (2019) Land use change: a key ecological disturbance declines soil microbial biomass in dry tropical uplands. Aust J Environ Manag 242:1-10

Trasar-Cepeda C, Leirósb MC, Gil-Sotres F (2008) Hydrolytic enzyme activities in agricultural and forest soils. Some implications for their use as indicators of soil quality. Soil Biol Biochem 40(9):2146-55

Vance ED, Brookes PC, Jenkinson DS (1987) An extraction method for measuring soil microbial biomass-C. Soil Biol Biochem 19(6):703-707

Vinhal-Freitas IC, Corrêa GF, Wendling B, Bobul'ská L, Ferreira AS (2017) Soil textural class plays a major role in evaluating the effects of land use on soil quality indicators. Ecol Indic 74:182-190

Waldrop MP, Zak DR, Sinsabaugh RL (2004) Microbial community response to nitrogen deposition in northern forest ecosystems. Soil Biol Biochem 36(9): 1443-1451

Wani SP, Chander G, Sahrawat KL, Pal DK, Pathak P, Pardhasaradhi G, Kamadi PJ (2015) Sustainable use of natural resources for crop intensification and better livelihoods in the rainfed semi-arid tropics of Central India. NJAS Wageningen J Life Sci 78:13-19

Wardle DA, Ghani A (1995) A critique of the microbial metabolic quotient $\left(\mathrm{qCO}_{2}\right)$ as a bioindicator of disturbance and ecosystem development. Soil Biol Biochem 27(12):1601-1610

Witt C, Gaunt JL, Galicia CC, Ottow JCG, Neue HU (2000) A rapid chloroformfumigation extraction method for measuring soil microbial biomass carbon and nitrogen in flooded rice soils. Biol Fertil Soils 30:510-519

Fang X, Wang Q, Zhou W, Zhao W, Wei Y, Niu L, Dai L (2014) Land use effects on soil organic carbon, microbial biomass and microbial activity in Changbai Mountains of Northeast China. Chin Geogr Sci 24:297-306

Yan B, Li J, Xiao N, Yue Q, Fu G, Liu G, Qiao M (2016) Urban-developmentinduced changes in the diversity and composition of the soil bacterial community in Beijing. Sci Rep 6:38811

Yang K, Zhu JJ, Zhang M, Yan Q, Sun OJ (2010) Soil microbial biomass carbon and nitrogen in forest ecosystems of Northeast China: a comparison between natural secondary forest and larch plantation. J Plant Ecol 3(3):175-182

Yao X-h, Min H, Lu Z-h, Yuan H-p (2006) Influence of acetamiprid on soil enzymatic activities and respiration. Eur J Soil Biol 42(2):120-6
Ye R, Wright AL, Inglett K, Wang Y, Orgam AV, Reddy KR (2009) Land-use effects on soil nutrient cycling and microbial community dynamics in the everglades agricultural area, Florida. Commun Soil Sci Plant Anal 40(17-18): $2725-2742$

Zeng DH, Hu YL, Chang SX, Fan ZP (2009) Land cover change effects on soil chemical and biological properties after planting Mongolian pine (Pinus sylvestris var. mongolica) in sandy lands in Keerqin, north-eastern China. Plant Soil 317:121-33

Zhang XB, Xu MG, Sun N, Wang XJ, Wu L, Wang BR, Li DC (2013) How do environmental factors and different fertilizer strategies affect soil $\mathrm{CO}_{2}$ emission and carbon sequestration in the upland soils of southern China? Appl Soil Ecol 72:109-118

Zhao D, Li F, Wang R (2012) The effects of different urban land use patterns on soil microbial biomass nitrogen and enzyme activities in urban area of Beijing, China. Acta Ecol Sin 32(3):144-149

Zhao D, Li F, Yang Q, Wang R, Song Y, Tao Y (2013) The influence of different types of urban land use on soil microbial biomass and functional diversity in Beijing, China. Soil Use Manag 29:230-239

\section{Publisher's Note}

Springer Nature remains neutral with regard to jurisdictional claims in published maps and institutional affiliations.

\section{Submit your manuscript to a SpringerOpen ${ }^{\circ}$ journal and benefit from:}

- Convenient online submission

- Rigorous peer review

- Open access: articles freely available online

- High visibility within the field

- Retaining the copyright to your article

Submit your next manuscript at $\boldsymbol{\nabla}$ springeropen.com 